\title{
Surface Treatment of Ti-Alloys
}

\author{
Fehim Findik* \\ BIMAS-RC Research Center, Sakarya University, Turkey
}

Submission: April 04, 2018; Published: June 11, 2018

*Corresponding author: Fehim Findik, BIMAS-RC Research Center, Sakarya University, Esentepe Campus, 54187 Sakarya, Turkey,

Email: findik@sakarya.edu.tr

Keywords: Ti-alloys; Surface treatment; Mechanical; Chemical and vacuum methods; Electro polishing.

\section{Introduction}

The aim of this paper is to overview of surface preparation methods for titanium based on mechanical, thermal as well as chemical and electrochemical treatments on medical applications. Methods generally concerning deposition or addition of foreign materials. This paper highlights the common values behind the diverse approaches related to titanium alloys.

\section{Surface processing requirements consider}

Several reasons can be mentioned for titanium alloys used for medical devices must be exposed to surface treatment techniques. By considering usual production processes, some techniques are simply understood. Dissimilar bulk is processing and production techniques for titanium alloys containing casting, forging, machining and rolling. During the conventional production, due to oxidation, contamination as well as residual stresses can happen during the deformation processes and as a result poor and non-uniform surface layer obtained. Therefore, natural surfaces are not suitable for medical applications. Hence further surface treatments are vital to provide the product an even surface finish. This will require removal of contaminants, oxidation films and structural defects and plastically deformed surface layers. One of the vital questions is the connection between material surface properties and biological responses in biomaterials study. Due to surface modification, structural and chemical surface properties influence material-bio system interactions [1-4]. Surface modification will open up new possibilities of developing new and improved medical devices.

\section{Properties of titanium surfaces}

There are three important facts to consider when dealing with titanium surfaces:

Titanium is a very reactive metal: Titanium is easily oxidized by numerous different media since it is a reactive metal. The oxidation kinetics are extremely fast (occurs in a few nanoseconds) [5]. Titanium is enclosed by an oxidized layer due to the high reactivity. The oxidized surface layer consists of the most stable titanium oxide and titanium dioxide (Ti02).

Ti02 is stable but chemically active: In contradiction of titanium, Ti02 is a stable compound which is resistant to chemical attack from most substances. The superb corrosion resistance of titanium is to a large extent due to the chemical stability of its surface oxide [6].

Surface properties depend on processing conditions: Formation conditions of the surface decide the chemical and physical properties of the material. This is correct for titanium since its oxides can cause various surface reactions and yields.

\section{Surface Processing Methods}

The properties of the surface treatment methods can be separated into three groups: a) cleaning and/or removal of native surface layers, b) modification of surface structure and topography, and c) modification of composition and structure of the oxide layer. When selecting method of surface processing, a selection must first be made if the native surface layer is to be detached or not.

\section{Mechanical methods}

Mechanical methods include treatment, shaping or removal of the material surface by physical forces applied by another solid material. Mechanical methods for surface treatment can be including removal of surface material by cutting action, and those where the treated material surface is deformed by grit blasting. The other mechanical methods of rolling and forging are not utilized for surface treatment.

\section{Chemical methods}

The methods are built on chemical reactions happening at the interface between titanium and a solution. Various chemical surface-treatment techniques are utilized in biomedical 
applications of titanium. Solvent cleaning, wet chemical etching and passivation treatments can be used in chemical methods for titanium applications in biomaterials research.

\section{Electrochemical methods}

Different chemical reactions occur at electrode surface placed in an electrolyte and they are called as electrochemical surface treatment methods. Anodic oxidation and electro polishing are the most applied methods. The specimen is made as anode in an electrochemical circuit in both cases (Figure 1a). A current flows through the circuit because of reduction and oxidation reactions at the electrodes when electrical power is attached. Depending on the select of electrolyte and potential, temperature, current etc., the process will have diverse properties on the anode surface.

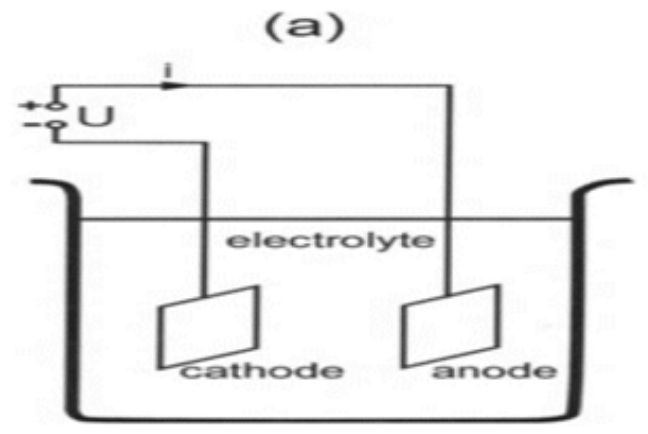

Figure 1A: Usual system for electrochemical surface preparation.

\section{Electropolishing}

For surface finishing of metal components, electro polishing is broadly utilizes as an industrial technique [7]. For titanium, the electrolyte typically contains an acid and alcohols mixture (60ml perchloric acid and $350 \mathrm{ml} \mathrm{n}$-butanol and $540 \mathrm{ml}$ methanol held at $-25{ }^{\circ} \mathrm{C}$ ). The aim of the electrolyte is double. It should cause (Figure 1b): a) electrode reactions that yield soluble products and $b$ ) the development of a viscous layer offer a mass transport-controlled reaction rate.

\section{(b)}

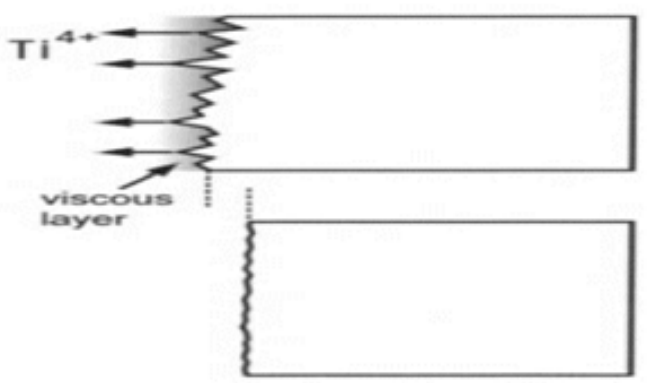

Figure 1B: During electro polishing a dissolution-rate-controlling viscous layer is formed at the anode resulting a smooth surface.

\section{Vacuum methods}

Vacuum methods are extensively used in surface technology of modern materials due to proposing superior control of processing circumstances. Ion implantation and glow discharge vacuum methods can be mentioned here as two well-known techniques.

\section{Conclusion}

Some surface preparation techniques of titanium alloys are reviewed for medical purposes [8-10]. Surfaces display different structural and chemical properties depending upon the preparation techniques. This can be either an advantage or a disadvantage. To meet the requirements for various uses, it permits the surface properties to be improved and this is an advantage.

\section{References}

1. Ahmad M, Gawronski D, Blum J, Goldberg J, Gronowicz G (1999) Differential response of human osteoblast-like cells to commercially pure (cp) titanium grades 1 and 4. J Biomed Mater Res 46(1): 121-131.

2. Buser D, Nydegger T, Oxland T, Cochran DL, Schenk RK, et al. (1999) Interface shear strength of titanium implants with a sand blasted and acid-etched surface: a biomechanical study in the maxilla of miniature pigs. J Biomed Mater Res 45(2): 75-83. 
3. Nishiguchi S, Nakamura T, Kobayashi M, Kim HM, Miyaji F, et al. (1999) The effect of heat treatment on bone-bonding ability of alkali-treated titanium. Biomaterials 20(5): 491-500.

4. Oji MO, Wood JV, Downes S (1999) Effects of surface-treated cp Ti and Ti6AI4V alloy on the initial attachment of human osteoblast cells. J Mater Sci Mater Med 10(12): 869-872.

5. Kasemo B, Lausmaa J (1986) Surface science aspects on inorganic biomaterials. CRC Crit Rev Bio compat 2: 335-380.

6. Tengvall P, Lundstrom I (1992) Physico-chemical considerations of titanium as a biomaterial. Clin Mater 9(2): 115-134.

7. Winter LS (1987) Electro polishing. In: Wood WG (Ed.), Surface
Cleaning, Finishing and Coating. Metals Handbook, American Society for Metals, Metals Park, Ohio, USA.

8. Yllmaz E, Gökçe A, Findik F, Gulsoy O (2017) Characterization of biomedical Ti-16Nb-(0-4) Sn alloys produced by powder injection molding. Vacuum 142: 164-174.

9. Yllmaz E, Gökçe A, Findik F, Gulsoy O (2017) Assessment of Ti-16Nb$\mathrm{xZr}$ alloys produced via PIM for implant applications. Journal of Thermal Analysis and Calorimetry, pp. 1-8.

10. Yllmaz E, Gökçe A, Findik F, Gulsoy O (2018) Metallurgical properties and biomimetic HA deposition performance of Ti-Nb PIM alloys. Journal of Alloys of Compounds 746: 301-313.

Your next submission with Juniper Publishers
will reach you the below assets
- Quality Editorial service
- Swift Peer Review
- Reprints availability
- E-prints Service
- Manuscript Podcast for convenient understanding
- Global attainment for your research
- Manuscript accessibility in different formats
( Pdf, E-pub, Full Text, Audio)
- Unceasing customer service
Track the below URL for one-step submission
https://juniperpublishers.com/online-submission.php

